\title{
PROMOSI PENGEMBANGAN KREATIVITAS PESERTA DIDIK DALAM PEMBELAJARAN
}

\author{
St. Nurjannah Yunus Tekeng \\ Fakultas Tarbiyah dan Keguruan UIN Alauddin Makassar \\ Kampus II: Jalan Sultan Alauddin Nomor 36 Samata-Gowa \\ Email: jannah.yustek@gmail.com
}

\begin{abstract}
Abstrak:
Setiap individu memiliki potensi untuk menjadi kreatif. Kreativitas lebih dari penggunaan imajinasi seseorang yang mencakup gaya hidup, ciri kepribadian, cara memahami dunia, dan cara hidup dan berkembang. Kreatifitas bergantung kepada dua faktor utama yaitu potensi bawaan (nature) dan pengaruh lingkungan (nurture). Untuk mendukung perkembangan potensikreatif dalam pendidikan, diperlukan desain pembelajaran yang menfasilitasi keaktifan dan keterlibatan peserta didik dalam mengeksplorasi kemampuannya, mencoba, menguji, menemukan ide-ide kreatif baru. Selain itu, pembelajar juga perlu mengembangkan sikap terbuka, dan menghargai pemikiran peserta didik. Melakukan hal tersebut adalah sebuah keharusan untuk menjawab tantangan zaman.
\end{abstract}

\begin{abstract}
:
Every individual has the potential to be creative. Creativity is more than the use of someone's imagination. This is a lifestyle, personality characteristic, and ways of understanding the world.Creativity depends on two main factors namely heredity (nature) and the influence of environment (nurture). To support the development of this students' creative potential, there is a need for an instructional design that facilitate the active participation of students in explorating their potential, trying out, examining, hypothesizing, and finding out a new creative idea. Besides, instructors should develop openness and respecting students thinking. Doing this is a way to respond tothedemand of the era.
\end{abstract}

Kata kunci:

Potensi kreatif, pengaruh lingkungan, pembelajaran untuk kreatifitas

DALAM sebuah kutipan talk show, Ken Robinson (ahli dalam bidang kreativitas dan seorang penasehat pemerintah Inggris tahun 1998 dalam bidang pendidikan kreativitas dan budaya) menyatakan "If you're not prepared to be wrong, you'll never come up with anything original". Pernyataan ini dimaksudkan bahwa pendidikan seharusnya mendukung peningkatan kreativitas dengan memberikan kesempatan kepada anak didik untuk bereksplorasi atau memberi ruang untuk mencoba berbagai hal dan menemukan sesuatu sebagai hasil berpikir kreatif. Penemuan ini kemudian seharusnya diapresiasi sebagai bentuk pemberian motivasi. Robinson juga menyatakan bahwa kreativitas mempunyai status yang sama dengan literacy. Oleh karena itu, keduanya harus diperlakukan sama dalam dunia pendidikan. Di samping itu, perkembangan lingkungan yang terus berubah secara pesat dan sulit diramalkan dalam era teknologi ditandai dengan penemuan-penemuan dan inovasi yang beragam menuntut seseorang untuk dapat memacu diri dan meningkatkan keterampilan tertentu untuk dapat berkompetisi. 
Huai-en menyatakan bahwa memasuki abad dua puluh satu, tantangan yang harus dipenuhi adalah ekonomi berbasis pengetahuan dan masyarakat berbasis informasi. Nampaknya dunia berkembang dengan cepat sehingga terkadang terasa ketinggalan ketika tidak belajar satu pengetahuanpun dalam sehari. Hal-hal yang berubah antara lain lingkungan tempat tinggal seperti kondisi kerja, gaya hidup, dan bahkan cara orang berkomunikasi. Oleh sebab itu, kesemuanya ini akan menuntut persyaratan baru (kualitas atau orang) dan dampak berikutnya pada tujuan dan model pelatihan atau pendidikan masa depan. ${ }^{1}$ Berdasarkan kenyataan ini, proses pendidikan di sekolah selayaknya mendukung pengembangan kreativitas anak didik dan bukan mematikannya dengan cara mengadopsi pembelajaran yang mempromosikan atau mendukung kreatifitas dan bukan lagi hanya berfokus pada hapalan fakta-fakta semata.

Kreativitas adalah kualitas yang ada di semua orang dan faktor kreativitas bervariasi dari orang ke orang baik dalam jumlah deposit awal, dan sejauh mana potensi ini direalisasikan dan dikembangkan. ${ }^{2}$ Menurut Runco, meskipun setiap orang memiliki potensi untuk menjadi kreatif, tetapi tidak semua orang menggunakan potensi tersebut. Kemungkinannya adalah mereka tidak memiliki kesempatan atau tidak memiliki keinginan melatih potensi kreatifnya. ${ }^{3}$

Bednar dkk., menyatakan bahwa "belajar" bukanlah proses pasif, tetapi sebuah proses aktif konstruktif dan mengarahkan diri sendiri di mana peserta didik membangun representasi pengetahuan internal yang diinterpretasi sendiri dari pengalaman belajar mereka. Representasi ini berubah terus-menerus berdasarkan makna yang orang lekatkan pada pengalaman. ${ }^{4} \mathrm{Hal}$ ini sesuai yang dijelaskan oleh salah satu aliran dalam konsruktivisme yaitu pandangan personalistik yang menfokuskan pada usaha individu. Aliran ini menekankan pada keunikan pola referensi internal individu, dan beranggapan bahwa ketika individu mengembangkan pengetahuan, akan selalu ada perbedaan di antara mereka dalam konsep dan makna. ${ }^{5}$

Terdapat semacam kesepakatan umum bahwa kesuksesan dalam hidup dan pendidikan pada khususnya bergantung kepada tingkat regulasi diri, motivasi dan kreativitas. Ketiga aspek belajar ini menjadi dasar kesuksesan akademik dan kelangsungan hidup di dunia yang kompetitif. Oleh karena itu, pendidikan tidak boleh mengabaikan relevansi dari sumber-sumber yang sangat diperlukan untuk mewujudkan potensi manusia. Harga dari tingkat ketidakterlibatan optimal pengaturan diri bersama-sama dengan potensi kreatif peserta didik adalah hilangnya kesempatan istimewa dimana mereka tahu bagaimana memanfaatkannya. ${ }^{6}$

Dalam pembelajaran, seringkali banyak terjadi apa yang disebut Amabile sebagai "pembunuhan kreativitas", 7 yaitu suatu kondisi dimana kegiatan belajar terlalu banyak dilakukan oleh guru, dan peserta didik tidak diberi kesempatan untuk mengeksplorasi potensi terbaik mereka. Oleh karena itu, alih-alih memberikan peserta didik dengan jawaban siap, mereka seharusnya terlibat dalam mencari jawaban sendiri. Guru juga harus melakukan yang terbaik untuk menghubungkan pengetahuan peserta didik ke dunia nyata untuk melibatkan pikiran dalam proses pembelajaran. Minat 
peserta didik dan emosinya harus distimulasi dan dihargai. Selain itu, pendidik seharusnya menetapkan standar yang tinggi dan harapan bagi peserta didik dan mendorong mereka untuk melakukan yang terbaik untuk mencapai standar dan harapan tersebut. Dengan kata lain, selama pembelajaran, peserta didik harus berada dalam modus berfungsi secara kreatif. Alasan di balik ini adalah untuk melibatkan minat dan perhatian peserta didik melibatkan otak dalam berpikir dinamis karena belajar yang baik dapat terjadi dengan mengorganisasikan pengetahuan intuitif peserta didik dan menempatkan mereka dalam konteks pengalaman kehidupan nyata di mana minat dan usaha mereka secara dinamis terlibat.

Mempromosikan pembelajaran yang mendukung pengembangan kreativitas peserta didik adalah penting karena untuk unggul di tempat kerja misalnya, masyarakat akan menuntut berbagai jenis pekerja, yaitu yang secara intrinsik termotivasi, mandiri, dan kreatif (mampu menghasilkan ide-ide baru). Para ahli di lapangan telah memprediksi bahwa individu dituntut yang memiliki kualitas seperti ketahanan dan fleksibilitas, cara kreatif, berpikir integratif, dan kekokohan psikologis tertentu dalam cara mereka menghadapi keadaan baru. ${ }^{8}$

Berdasarkan uraian pada latar belakang, maka tujuan penulisan artikel ini adalah untuk memberikan penjelasan tentang pentingnya pengembangan kreatifitas individu dalam pembelajaran dengan menyajikan pengertian kreatifitas, faktor-faktor yang berpengaruh terhadap pengembangan kreatifitas, kerangka teoritis pengembangan kreatifitas, dan kriteria pembelajaran yang mempromosikan pengembangan kreatifitas dalam pembelajaran.

\section{PENGERTIAN KREATIVITAS}

Kreatifitas menurut Plucker dkk., adalah interaksi antara bakat, proses, dan lingkungan di mana seseorang atau kelompok menghasilkan sebuah produk yang perseptif, yaitu yang original dan bermanfaat sesuai definisi yang berlaku dalam sebuah kontek social. ${ }^{9}$ Dua karakteristik utama yang diasosiasikan dengan kreativitas adalah original dan bermanfaat. ${ }^{10}$ Sternberg dalam Al-Dhobaiban menyatakan bahwa sejumlah peneliti sepakat dengan definisi yang memandang kreativitas sebagai kemampuan untuk menghasilkan hasil kerja yang baru (yaitu orisinil dan tak terduga), tinggi dalam kualitas, dan tepat (yaitu, berguna dan memenuhi hambatan tugas). ${ }^{11}$

Craft menyatakan bahwa kreatifitas dapat dilihat sebagai cara untuk memperluas apa yang seseorang ketahui, pahami, dan dapat dilakukan (pengertian ini dekat dengan makna kreatifitas sebagai aspek dari belajar). Craft menjelaskan bahwa jika seseorang mempelajari sesuatu yang baru (dalam tingkatan usia berapapun), dia membuat koneksi antara ide-ide dan memaknainya untuk dirinya. Jadi pada dasarnya menurut dia, seseorang mengkonstruksi pengetahuan, dan dalam konteks ini dapat digambarkan dimana seseorang menjadi kreatif. Semakin seseorang terlibat dalam membuat makna, semakin luas pengetahuan yang dimiliki dan ini merupakan situasi yang dapat terjadi ketika seseorang dalam proses bermain dengan imajinasi. ${ }^{12}$ 
Torrance dalam Al-Dhobaiban menggambarkan kreativitas sebagai proses penginderaan masalah atau kesenjangan dalam informasi, membentuk ide atau hipotesis, pengujian dan memodifikasi hipotesis, dan mengkomunikasikan hasil. Kreativitas lebih dari penggunaan imajinasi seseorang. Ini adalah gaya hidup, ciri kepribadian, cara memahami dunia, dan cara hidup dan berkembang. Menjadi kreatif berarti mengeksplorasi ide-ide baru, tempat-tempat baru, dan aktivitas baru. Hal ini juga mengembangkan kepekaan terhadap masalah manusia. ${ }^{13}$

Adams menyatakan bahwa kreativitas muncul melalui penyatuan tiga komponen, yaitu: (1) pengetahuan, yaitu semua pemahaman yang relevan individu bawa untuk melakukan usaha kreatif; (2) berpikir kreatif, yaitu berkaitan dengan bagaimana orang mendekati masalah dan tergantung pada kepribadian dan gaya berpikir atau bekerja; (3) motivasi, yaitu yang secara umum diterima sebagai kunci produksi kreatif dan motivator yang paling penting bersifat intrinsik, dan minat dalam pekerjaan itu sendiri. ${ }^{14}$

\section{TEORI KREATIVITAS}

Teori perkembangan menjelaskan bahwa kreativitas berkembang dari waktu ke waktu. Dimulai dari potensi kreatif mengarah kepada pencapaian kreativitas sebagai hasil dari interaksi individu dengan lingkungan. ${ }^{15}$ Ini berarti bahwa kreatifitas didukung oleh dua faktor utama yaitu adanya potensi bawaan individu (nature) dan faktor lingkungan (nurture) yang mendukung perkembangan potensi tersebut. Namun Esquivel dalam Lin menyatakan bahwa para pendukung pendidikan kreativitas telah menekankan variabel lingkungan di atas faktor genetik, sebagai aspek yang lebih relevan dan layak untuk dipertimbangkan dalam mempengaruhi pengembangan kreativitas. ${ }^{16}$

Teori kreatifitas Amabile dengan "componential model of creativity" menyatakan bahwa dibutuhkan tiga variabel penting yang memungkinkan terjadinya kreatifitas. Ketiga variabel tersebut adalah: (1) domain-relevan skill, yaitu termasuk pengetahuan, keterampilan teknis, dan bakat khusus yang mungkin dimiliki oleh individu dan penting untuk domain tertentu. Sebagai contoh, jika seseorang ingin menjadi dokter yang kreatif, dia harus memiliki pengetahuan tentang obat; (2) Creativity-relevant skills, yaitu faktor personal yang terkait dengan kreatifitas secara umum seperti toleransi terhadap ambiguitas, disiplin diri, dan keinginan untuk mengambil resiko yang sesuai (jika penekanannya pada orangnya), dan keterampilan kognitif yang melatarbelakangi kreatifitas (jika penekanannya pada proses); (3) task-motivation, yaitu motivasi individu terhadap tugas yang diberikan. Kreatifitas lebih terasosiasi dengan motivasi intrinsik dibandingkan motivasi ekstrinsik, yaitu kondisi dimana seseorang diarahkan oleh keyakinan diri akan manfaat dan kesenangan mengerjakan sebuah tugas. ${ }^{17}$

Kreativitas dapat diajarkan ${ }^{18}$ dan umumnya ada tiga premis yang mendasari pendekatan kreativitas dalam pendidikan: pertama, adalah pandangan bahwa kreativitas dapat dikembangkan. Kedua, adalah bahwa semua individu memiliki potensi untuk menjadi kreatif. Ketiga, adalah bahwa kreativitas secara luas dipengaruhi oleh 
lingkungan psiko-fisik peserta didik. ${ }^{19}$ Implikasi pengembangan kreatifitas melalui pendidikan dapat diimplementasikan melalui tiga aspek yaitu: pertama adalah pembelajaran yang menfasilitasi praktek yang bersifat kreatif dan inovatif yang menstimulasi perkembangan kecerdasan majemuk, berpikir tingkat tinggi, kesempatan untuk mengeksplorasi dan menyelesaikan masalah. Kedua adalah menciptakan lingkungan (eksternal dan sosial) yang menstimulasi dan mendukung motivasi dan antusiasme peserta didik, dan perilaku kreatif. Ketiga adalah etos mengajar yaitu yang memelihara sikap terbuka terhadap ide-ide atau perilaku kreatif, tidak otoriter, fleksibel, dan menghargai berpikir mandiri. ${ }^{20}$

\section{FAKTOR-FAKTOR YANG MEMPENGARUHI KREATIVITAS}

Secara konseptual, kreativitas didefinisikan dalam hal imajinasi, berpikir divergen, fantasi, intuisi, rasa ingin tahu, pemecahan masalah, dan kombinasi yang berbeda dari faktor-faktor ini. Sedangkan menurut Gomez, ada beberapa faktor yang mendukung kreativitas yaitu berpikir konvergen dan divergen, lingkungan, akses ke alat manipulatif untuk tes ide (Teknologi Komputer), dan berpikir reflektif atau evaluasi pemikiran: ${ }^{21}$

\section{Berpikir Konvergen dan Divergen}

Copley dalam Gomez menyatakan bahwa ada dua cara berpikir yaitu konvergen dan divergen. Berpikir konvergen ditandai oleh reproduksi konsep dan penerapan respon yang dikenal dengan situasi baru. Berpikir divergen, di sisi lain, melibatkan fluensi, fleksibilitas, dan orisinalitas, dan pada dasarnya berkaitan dengan produksi sejumlah besar ide-ide baru. ${ }^{22}$ Kedua model berpikir ini sangat penting untuk pengalaman pemecahan masalah. Sebuah gagasan dianggap kreatif ketika membawa wawasan baru pada situasi tertentu. Kneller dalam Gomez menyatakan bahwa proses kreativitas mencakup kemampuan untuk mengubah cara orang menghadapi masalah, menghasilkan ide-ide yang relevan dan tidak biasa, untuk mendefinisikan kembali masalah atau beberapa aspek. ${ }^{23}$

\section{Faktor Lingkungan}

Sudah dikenal sejak dahulu bahwa untuk mengembangkan kreativitas peserta didik membutuhkan sebuah lingkungan responsif yang didefenisikan oleh Torrance sebagai tempat di mana seseorang terlibat dalam kegiatan mengabsorsi, mendengarkan, melawan kritik dan ejekan, dan memperdalam sesuatu yang dangkal. Situasi di mana setiap usaha yang jujur untuk belajar dihargai dengan hadiah yang cukup untuk memastikan upaya yang berkelanjutan. Jadi fokusnya lebih kepada potensi dan bukan pada norma. ${ }^{24}$ Craft menyebutkan bahwa belajar yang kreatif dapat terjadi dalam lingkungan yang memiliki kriteria yaitu adanya inovasi, kepemilikan, kontrol, dan relevansi. ${ }^{25}$

Proses kreatif menurut Axelrod dapat didorong dalam semua kegiatan instruksional. Mengajar secara kreatif berarti menyiapkan lingkungan belajar yang mendorong peserta didik untuk melihat esensi serta detail dari subjek, untuk merumuskan 
dan memecahkan masalah, untuk melihat keterkaitan dan saling keterkaitan antara berbagai bidang, untuk mengambil dan bereaksi terhadap ide-ide baru, dan untuk memasukkan unsur kejutan dalam pekerjaan mereka. ${ }^{26}$ Ahli kreativitas berulang kali menekankan pentingnya menemukan kedua masalah dan solusi. Ide asli harus aktif dicari. Misalnya, seorang mahasiswa ditugaskan laporan lisan mungkin didorong untuk menambah evaluasi pribadi dan mengaplikasikan teknik unik yang ia inginkan. Terlalu sering, pemikiran yang benar membutuhkan satu solusi dan satu metode telah ditekankan. Solusi alternatif untuk masalah yang tidak perlu sebelumnya telah disarankan oleh orang lain untuk menjadi layak. Alternatif tidak ditemukan dalam buku teks harus diminta dari peserta didik. Mereka harus dipaksa untuk mengajukan lebih dari satu alternatif, dan teknologi komputer dapat membantu. ${ }^{27}$

\section{Akses ke Alat Manipulatif untuk Tes Ide (Teknologi Komputer)}

Sebagaimana yang diungkapkan oleh Clement dan Saraman bahwa kehadiran teknologi apakah digunakan untuk membaca atau menulis, untuk memperoleh pengetahuan dan wawasan ilmu pengetahuan, matematika dan yang lainnya, untuk mengekspresikan diri, atau untuk belajar dalam media baru, komputer dapat mendukung ekspresi dan pengembangan kreativitas. ${ }^{28}$ Demikian pula Hollenbeck dan Hollenbeck menyatakan bahwa berbagai penelitian dan berbagai studi lainnya telah menunjukkan bahwa penggunaan multi media dalam kelas meningkatkan kreativitas, inovasi, pemecahan masalah dan meningkatkan komunikasi antara orang. ${ }^{29}$

\section{Berpikir Reflektif dan Evaluasi Pemikiran}

Pemikiran reflektif dan evaluasi pikiran adalah dasar dari proses kreativitas. Secara umum, ide dievaluasi untuk tujuan memfasilitasi proses pemecahan masalah di setiap langkah. Namun, evaluasi terus menerus membatasi generasi ide. Sebuah suspensi putusan memungkinkan seseorang untuk memeriksa lebih lanjut ide-ide yang tampaknya liar atau tidak mungkin. Ide-ide yang salah mungkin benar dalam analisis akhir. Penekanan bergeser dari validitas suatu titik tertentu terhadap kegunaannya dalam memproduksi pengaturan atau pola-pola baru. Penghentian penilaian memungkinkan ide untuk bertahan cukup lama untuk menghasilkan ide-ide lain dan mendorong orang-orang yang mungkin memiliki masukan yang berguna tetapi takut menyatakan pandangan mereka karena takut salah. Teknik ini dapat digunakan dalam berbagai cara dalam kelas. ${ }^{30}$

\section{PEMBELAJARAN YANG MEMPROMOSIKAN PENGEMBANGAN KREATIVI- TAS}

Mengajar untuk kreativitas menurut National Advisory Committee on Creative and Cultural Education(NACCCE) di London, adalah mengajar berdasarkan prinsip-prinsip kreativitas yaitu mendorong peserta didik untuk percaya pada identitas kreatif mereka, mengidentifikasi kemampuan kreatif, dan mengembangkan kreativitas dengan mengembangkan beberapa kemampuan umum dan sensitifitas kreativitas seperti rasa ingin tahu, mengenal dan mempunyai pengetahuan yang luas tentang pro- 
ses kreatif yang membantu pengembangan kreativitas mendorong dan memberikan peluang untuk menjadi kreatif. ${ }^{31}$

Jeffrey dan Craft secara specifik mengemukakan kriteria pembelajaran untuk kreatifitas (teaching for creativity), yaitu pembelajaran yang menfokuskan kepada pengembangan perilaku dan berpikir kreatif peserta didik. Kriteria tersebut adalah: (1) mendelegasikan kontrol kepada peserta didik dan memotivasi kontribusi yang inovatif; (2) pembelajar meletakkan nilai dan kepemilikan peserta didik ketika mereka menghasilkan sebuah inovasi; (3) memotivasi peserta didik untuk bertanya, mengidentifikasi masalah atau isu; (4) menawarkan peserta didik kesempatan untuk berdebat dan mendiskusikan pemikiran mereka; (5) memotivasi peserta didik menjadi mitra dalam pembelajaran yang menghasilkan kontrol yang lebih jauh terhadap strategi belajar mereka; (6) memprioritaskan peserta didik sebagai agen dalam belajar; (7) memotivasi "belajar kreatif", yaitu konstruksi "pebelajar kreatif" dan yang lebih tinggi lagi adalah "individu kreatif" ${ }^{32}$

Mempromosikan pembelajaran yang mendukung kreatifitas dapat diidentifkasi melalui beberapa indikator. Sebagi contoh, Morris menjelaskan bahwa indikator perilaku kreatif yang ditunjukkan oleh peserta didik di dalam kelas adalah: (1) mempertanyakan dan menantang, yaitu memiliki rasa ingint tahu, mempertanyakan, memberikan tantangan, dan tidak mesti mengikuti aturan; (2) membuat koneksi dan melihat hubungan, yaitu berfikir lateral dan membuat asosiasi antara hal-hal yang biasanya tidak terkoneksi; (3) melihat kedepan apa yang mungkin terjadi, yaitu mereka melihat kemungkinan-kemungkinan, bertanya "bagaimana jika?", menggambarkan alternatif, dan melihat sesuatu dari perspetif yang berbeda; (4) mengeksplorasi ide dan pilihan, yaitu mereka bermain dengan ide-ide untuk menghasilkan ide kreatif; (5) merefleksi secara kritis terhadap ide, tindakan, dan hasil, yaitu mereka mereviu kemajuan, mengharapkan dan menggunakan umpan balik, mengkritik secara konstruktif, dan membuat pengamatan perseptif. ${ }^{33}$ Untuk mendorong dan menfasilitasi hal-hal tersebut di atas, memerlukan perubahan dalam cara pembelajar melaksanakan atau mendesain pembelajaran.

Berdasarkan tiga variabel penting yang dibutuhkan yang memungkinkan terjadinya kreatifitas sebagaimana yang dikemukakan oleh Amabile yaitu keterampilan yang relevan dengan domain, keterampilan yang relevan dengan kreatifitas, dan motivasi tugas, ${ }^{34}$ maka merujuk kepada tiga variabel ini, hal-hal yang harus dipenuhi untuk mendukung kreatifitas peserta didik adalah membekali peserta didik pengetahuan dan keterampilan yang dibutuhkan sesuai dengan keahliannya, melatih dan menumbuhkan sikap-sikap yang mendukung terjadinya perilaku kreatif, dan mendesain tugas yang dapat menimbulkan ketertarikan personal atau menumbuhkan motivasi intrinsik.

Merujuk kepada salah satu faktor penting yang mempengaruhi perkembangan kreativitas yaitu kegiatan berpikir reflektif, salah satu model pembelajaran yang dapat menunjang faktor tersebut adalah pembelajaran berbasis regulasi diri. Model pembelajaran instruksional ini mengakomodir komponen-komponen yang bersum- 
ber dari faktor tesebut. Implementasi model pembelajaran ini memberikan kesempatan pada peserta didik untuk dapat melakukan praktek kegiatan refleksi yang dapat meningkatkan keterampilan memonitor, mengevaluasi, dan menyesuaikan performa mereka selama proses belajar. Refleksi diri ini menurut Schunk, secara bertahap diharapkan dapat membantu mereka mendapatkan strategi belajar yang dapat meningkatkan prestasi mereka secara efektif dan memudahkan pemecahan masalah. ${ }^{35}$ Teori Regulasi diri memberi penekanan pada kemampuan individu untuk membimbing kegiatan mengarahkan tujuan dan kinerja dengan menetapkan standar mereka sendiri dan memonitor kemajuannya menuju standar-standar tersebut. ${ }^{36}$

Ogawa menjelaskan bahwa pembelajaran dengan regulasi diri atau disebut juga pembelajaran mandiri adalah sebuah proses di mana sebuah rencana individu, mengatur, menginstruksikan, memonitor, dan mengevaluasi diri sendiri pada berbagai tahapan proses pembelajaran. Model pembelajaran ini menekankan gagasan bahwa peserta didik yang aktif dan konstruktif dalam proses belajar, belajar dengan membangun makna mereka sendiri, tujuan, dan strategi atas dasar ketersediaan informasi internal dan eksternal. ${ }^{37}$ Vermunt dan Verloop menyatakan bahwa ketika belajar dipahami lebih sebagai konstruksi pengetahuan yang bersifat mandiri dari pada sebagai mengambil pengetahuan yang sudah ada (existing external knowledge), maka peran mengajar berubah dari transmisi pengetahuan kepada mendukung dan membimbing konstruksi pengetahuan mandiri. Proses peserta didik mengkonstruksi pengetahuan kemudian menjadi objek usaha pembelajar. Ini mempersyaratkan teori-teori pembelajaran yang tegas yang didasarkan pada analisis proses belajar peserta didik. ${ }^{38}$

\section{SIMPULAN}

Berdasarkan uraian di atas, dapat disimpulkan bahwa merupakan sebuah tuntutan untuk mendukung pembelajaran berpikir kreatif atau pengembangan kreatifitas peserta didik. Hal tersebut didasarkan pada perkembangan zaman yang menuntut kreatifitas seseorang, dan berdasarkan asumsi bahwa setiap orang memiliki potensi untuk menjadi kreatif dan faktor lingkungan memiliki peran yang sangat penting dalam menstimulasi dan menfasilitasi perkembangan potensi kreatif tersebut. Pengembangan model pembelajaran yang mempromosikan pengembangan kreatifitas perlu memperhatikan faktor-faktor atau variabel-variabel yang berpengaruh dan prinsipprinsip implementasinya sehingga pengembangan potensi kreatifitas peserta didik menjadi maksimal.

\section{CATATAN AKHIR:}

1. Yang Huai-en, To Foster Students creativity Through Teaching, Beijing Technology and Business University, A paper presented on the Fourth International Conference on ELT, 2004.

2. N. A. Al-Dhobaiban, Exploring the relationship between self-regulation and creativity, Unpublished dissertation, Alabama: The University of Alabama, 2005.

3. M. A. Runco, Theories and Themes: Research, Development, and Practice, USA: Elsevier Academic Press, 2007. 
4. J. D. Vermunt and N. Verloop, Congruence and friction between learning and teaching, Learning and Instruction, Vol. 9 257-280, 1999.

5. B. Joyce, and M. Weil, Models of Teaching (5 $5^{\text {th }}$ edition), New Delhi: Prentice-Hall of India, 2003.

6. N. A. Al-Dhobaiban, op.cit.

7. N. A. Al-Dhobaiban, ibid.

8. N. A. Al-Dhobaiban, ibid.

9. J. C. Kaufman, J. A. Plucker, and J. Baer, Essentials of Creativity Assessment, New Jersey; John Wiley and Son. Inc., 2008.

10. A. J. Starko, Creativity in the Classroom (Fourth Edition), New York: Routledge, 2005.

11. N. A. Al-Dhobaiban, op.cit.

12. A. Craft, Creativity in Schools: Tensions and Dilemmas, London: Routledge, 2005, p.52

13. N. A. Al-Dhobaiban, op.cit.

14. K. Adam, The Source of Innovation and Creativity, A Paper Commissioned by The National Center on Education and Economy For The New Commission On The Skills on The American Workforce, 2005.

15. M. A. Runco, op.cit.

16. Yu-Sien Lin, Fostering Creativity through Education - A Conceptual Framework of Creative Pedagogy, Creative Education, Vol.2, No.3, 149-155, 2011.

17. J. C. Kaufman, J. A. Plucker, and J. Baer, op.cit.

18. Yu-Sien Lin, op.cit.

19. Rashmi, Fostering Creativity: A Four Elemental Model of Creative, Journal of Education and Practice, Vol 3, No 12, 2012.

20. Yu-Sien Lin, op.cit.

21. J. G. Gomez, What Do We Know About Creativity?.The Journal of Effective Teaching, Vol. 7, No. 1, 31-43, 2007

22. J. G. Gomez, op.cit.

23. J. G. Gomez, ibid.

24. J. G. Gomez, ibid.

25. A. Craft, op.cit. p.47

26. A. Reid and P. Petocz, Learning domains and the process of creativity, TheAustralian Educational Researcher, 31(2), 2004.

27. J. G. Gomez, op.cit.

28. J. G. Gomez, ibid.

29. J. G. Gomez, ibid.

30. J. G. Gomez, ibid.

31. B. Jeffrey and A. Craft, Teaching creatively and teaching for creativity: distinctions and relationships, Educational Studies, 30(1), pp. 77-87, 2004.

32. A. Craft, op.cit., p.42

33. W. Morris, Creativity in the classroom - what does it look like?, Belgium: JPB.Com., 2006.

34. J. C. Kaufman, J. A. Plucker, and J. Baer, op.cit.

35. M. Kobayashi and B. Lockee, Evidence Approaches For Self-Regulated Learning, Reviesta Reginal De Investigacion Educativa (5) 32-44. 2008.

36. K. D. Vohs and R. F. Baumeister, Handbook of Self-Regulation:Research, Theory, and Applications, New York: The Guilford Press., 2011.

37. A. Ogawa, Facilitating Self-Regulated Learning: An Exploratory Case of Teaching a University Course on Japanese Society, International Journal of Teaching and Learning in Higher Education, Volume 23, Number 2, 166-174, 2011.

38. J. D. Vermunt and N. Verloop, op.cit. 


\section{DAFTAR PUSTAKA:}

Adam, K., The Source of Innovation and Creativity, A Paper Commissioned by The National Center on Education and Economy For The New Commission On The Skills on The American Workforce, 2005.

Al-Dhobaiban, N. A., Exploring the relationship between self-regulation and creativity, Unpublished dissertation, Alabama: The University of Alabama, 2005.

Craft, A., Creativity in Schools: Tensions and Dilemmas, London: Routledge, 2005.

Gomez, J. G., What Do We Know About Creativity?.The Journal of Effective Teaching, Vol. 7, No. 1, 31-43, 2007.

Huai-en, Yang, To Foster Students creativity Through Teaching.Beijing Technology and Business University, A paper presented on the Fourth International Conference on ELT., 2004.

Joyce, B., Weil, M., Models of Teaching (5th edition), New Delhi: Prentice-Hall of India, 2003.

Jeffrey, Bob \& Craft, Anna, Teaching creatively and teaching for creativity: distinctions and relationships, Educational Studies, 30(1), pp. 77-87. 2004.

Kaufman, J. C., Plucker, J. A., and Baer, J., Essentialsof Creativity Assessment, New Jersey; John Wiley and Son. Inc., 2008.

Kobayashi, M., \&Lockee, B., Evidence Approaches For Self-Regulated Learning, Reviesta Reginal De Investigacion Educativa (5) 32-44, 2008.

Kramarski, Bracha, dan Michalsky, Tova, Investigating preservice teachers' professional growth in self-regulated learning environments, Journal of Educational Psychology, Vol 101(1), 161-175, 2009.

Lin, Yu-Sien, Fostering Creativity through Education - A Conceptual Framework of Creative Pedagogy, Creative Education, Vol.2, No.3, 149-155, 2011.

Morris, W., Creativity in the classroom - what does it look like?, Belgium: JPB. Com., 2006.

Ogawa, Akihiro, Facilitating Self-Regulated Learning: An Exploratory Case of Teaching a University Course on Japanese Society, International Journal of Teaching and Learning in Higher Education, Volume 23, Number 2, 166-174, 2011.

Rashmi, Fostering Creativity: A Four Elemental Model of Creative, Journal of Education and Practice, Vol 3, No 12, 2012.

Reid, A. \& Petocz, P., Learning domains and the process of creativity, TheAustralian Educational Researcher, 31(2), 2004.

Runco, M. A., Theories and Themes: Research, Development, and Practice, USA: Elsevier Academic Press., 2007.

Starko, A. J., Creativity in the Classroom (Fourth Edition), New York: Routledge, 2005.

Wang, Hao-Chuan, Chang, Chun-Yen, and Li,Tsai-Yen, Automated Scoring for Creative Problem Solving Ability with Ideation-Explanation Modeling, Appear in Proceedings of The 13th International Conference on Computers in Education (ICCE2005), 2005

Wang, Hao-Chuan, Chang, Chun-Yen, and Li,Tsai-Yen, Assessing creative problem-solving with automated text grading, Computers \& Education, doi:10.1016/j.compedu.2008.01.006, 2008.

Vermunt, J.D., and Verloop , N., Congruence and friction between learning and teaching, Learning and Instruction, Vol. 9 257-280, 1999.

Vohs, K. D.\& Baumeister, R. F., Handbook of Self-Regulation: Research, Theory, and Applications, New York: The Guilford Press., 2011. 